\title{
音節連鎖特性に着目した対話文の言い直し表現の抽出法
}

\author{
荒木 哲郎 池原 悟 ${ }^{\dagger \dagger}$ 橋本 昌東 ${ }^{\dagger \dagger}$
}

会話文では，言い直しなどのて長な表現が含まれ，解析を困難にしている，本論文で は，言い直し表現は繰り返し型が多く，また，文節境界に挿入されやすいことに着目 して，べた書きで音節標記された会話文を対象に，これを抽出する方法を提案した。 提案した方法は，言い直しを含んだべた書き音節列をマルコフ連鎖モデルを用いて文 節単位に分割する処理と，それによって得られた文節境界を手がかりに文節間の音節 列の類似性を評価して言い直し音節列を抽出する処理の 2 つの処理から構成される. 具体的には, 第 1 の処理では, 言い直しの表現を含む文節境界の推定に適した文節境 界推定法を提案し，第 2 の処理では，文節境界の使い方の異なる 3 つのマッチングの 方法を提案した。 また，これらの 2 つの方法を組み合わせたときの言い直し表現の抽 出精度を計算によって推定すると共に, その結果を総合的な実験結果と比較して提案 した方法の効果を評価した．ATRの「旅行に関する対話文」のコーパス（その内，言 い直しは 106 個所）を用いて実験評価した結果によれば，言い直し表現の抽出精度は 第 2 の処理の方法に強く依存し，再現率を重視する場合は，再現率 $80.2 \%$ (その時, 適合率 $84.2 \%$ ），また，適合率を重視する場合は，適合率 $94.9 \%$ （その時，再現率 $52.8 \%$ ）の精度が得られることが分かった。

キーワード： 仮文節境界，対話文，言い直し，音節列

\section{A Method to Detect Self-repair Syllable Strings in Spontaneous Speech using Markov Model}

\author{
Tetsuo Araki ${ }^{\dagger}$, Satoru Ikehara ${ }^{\dagger \dagger}$ and Masato Hashimoto ${ }^{\dagger+}$
}

This paper proposes a method to detect self-repair strings included in spontaneous speech by Markov models of syllables. These strings are assumed to be represented with syllable strings obtained correctly by acoustic processing. The method comprises the following two steps: The first step is to determine the provisional bunsetsu boundaries of a non-segmented syllable sentence with self-repair strings. We improved the method which has been proposed to find the provisional bunsetsu boundaries of correct sentences by Markov models, to be applicable to sentences with self-repair. The second step is to detect self-repair strings, which are inserted in the location of bunsetsu boundaries. In this step, we proposed three methods of pattern matching to detect these strings. This method is applied to detect self-repair strings in ATR dialogue corpus. It is confirmed that the method is effective to detect self-repair strings inserted in bunsetsu boundaries.

KeyWords: provisional bunsetsu boundaries, dialogue, self-repair, syllable strings 


\section{1 はじめに}

従来，日本語記述文の解析技術は大きく進展し，高い解析精度 (宮崎 1984; 宮崎, 大山 1986) が得られるようになったが，音声会話文では，助詞の省略や倒置などの表現が用いられること， 圥長語や言い直しの表現が含まれることなどにより，これを正しく解析することは難しい．

省略や語順の変更に強い方法としては, 従来, キーワードスポッテイングによって文の意味 を抽出する方法 (河原, 松本 1995; 伝 1996; 山本, 小林, 中川 1992) が考えられ, 日常会話に近い 「自由発話」への適用も試みられている. 圥長語に対しては, 圥長語の出現位置の前後にポーズ が現れることが多いこと, またて長語の種類がある程度限定できることから, 頻出するて長語 を狙い撃ちして抽出する方法や上記のキーワードスポッテイングの方法によってスキップする 方法などの研究が行なわれている (中川, 小林 1995; 村上, 嵯峨山 1991, 1995).

言い直し表現の抽出では, 圥長語の場合のように予娮い直しの夕イプを限定することが難 しいが，音響的な特徵に基づく解析や言語的な特徵に基づく解析が試みられている。このうち， 音響的特徵による方法としては，D Pマッチングによるワードスポッテイングを用いた方法が 提案されているが, 繰り返し型の言い直しを対象にした実験では，40\%程度の抽出精度しか得 られておらず (中川, 小林 1995), また音素モデルにガーベージモデルを使用した方法では，180 文中に言い直し表現が 21 件存在する場合の実験結果は，67\%の抽出精度に留まっている(井) 上, 竹田，山本 1994)。これらの研究結果に見られるように，音響的な情報に基づいて抽出する だけでは限界があるために，言語の文法や意味的な情報を用いることが期待される.

従来，言語的な特徵による方法としては，英語では，発話を記録したテキストを対象に，音 響的な特性を利用して言い直し表現を抽出する方法が提案され，90\%の抽出精度が得られてお り (Shriberg, Bear, and Dowding 1992; Nakatani and Hirschberg 1994), 日本語では, 漢字か な混じり表記の文を対象に, 文法的な解析によって言い直し表現を抽出する方法が提案され, 108 個所の言い直し抽出実験では 70\%の精度が得られている (佐川, 大西, 杉江 1994).さらに, 対話文中に含まれる言い直し表現の言語的な構造を詳細に調べる方法 (中野, 島津 1997; 伝, 春 木, 石崎 1997）が考えられている.しかし，このような漢字かな混じり文を対象とした方法は, 言い直しの検出に単語品詞情報や構文解析情報などを利用しているために, 音声認識されたか な文字列（言い直し表現を含めた対話文）に対してそのまま適用することが困難である。これ に対して, 音素モデルの単語 trigram などを利用して言い直し部分をスキップさせる方法や未 知語抽出の単語モデルを用いて未知語を言い直しとして抽出する方法がある (Wilpon, Lee, and Rabiner 1990; Asadi, Schwartz, and Makhoul 1991; 村上, 嵯峨山 1995). この方法は単語数が

†福井大学工学部知能システム工学科, Department of Human and Artificial Intelligence Systems, Faculty of Engineering, Fukui University

†† 鳥取大学工学部知能情報工学科, Department of Information and Knowledge Engineering, Faculty of Engineering, Tottori University

†††日本電気株式会社 第 2 パーソナル C\&C 事業本部, Second Personal C\&C Operations Unit, NEC Corporation 
制限されることが問題である.

本論文では，音響処理によって得られたべた書き音節文を対象に，言語的な情報の一部であ る音節の連鎖情報に着目して，言い直し音節列を抽出する方法を提案する。この方法は，単語 数が限定されない利点をもつ. 具体的には, 次の 2 段階の処理によって言い直しの抽出を行な う.まず，最初の第 1 段階では，言い直しの音節列が文節境界に挿入されることが多いことに 着目して，言い直しを含んだべた書き音節文の文節境界を推定する。音節文字列の文節境界の 推定では，すでにマルコフ連鎖を用いた方法が提案されているが，言い直しを含む音節列では， 言い直し音節列の近傍で音節連鎖の結合力が弱くなる傾向があるため，この方法では，正しく 文節境界位置を求めることが難しくなると予想される。そこで，この問題を解決するために， すでに提案された方法 (荒木, 池原, 土橋, 笹島 1997) を, 前方向・後方向の双方向から音節連鎖 の結合力が評価できるように改良する。

次に第 2 段階では，第 1 段階で得られた文節境界を用いて文節を抽出し，抽出した文節を相 互に比較して言い直し音節列を抽出する。マッチングの方法としては，(i) 1 つの文節境界を起 点に, 繰り返し部分を含む文字列を抽出する方法, (ii) 連続した 2 つの文節境界のそれぞれを起 点とする文字列を比較する方法, (iii) 連続した 3 つのすべての文節境界を用いて, 抽出された 2 文節を比較する方法の 3 種類を提案する.

また, これらの方法を「旅行に関する対話文 (ATR)」 (江原, 井上, 幸山, 長谷川, 庄山, 森元 1990)のコーパスに適用し，個別実験結果から得られる言い直し表現の抽出精度を計算によっ て推定すると共に，その結果を総合的な実験結果と比較して，提案した方法の効果を確認する.

\section{2 言い直し表現の特徴と抽出の方針}

\section{1 言い直し表現の特徵}

言い直し（以下では「換言」とも言う）とは，下記の例に示すように，前に言ったことの誝 りを訂正してもう一度言ったり，話の途中で言い淀んでしまってもう一度言うといった表現を 示す.

$$
\begin{aligned}
& \text { 「はい（かしこ）かしこまりました.」 } \\
& \text { 「（わたし）わたくし鈴木が承りました.」 }
\end{aligned}
$$

以下では，言い直しによって訂正される対象となる部分（括弧で示した部分）を「換言前音 節列（又は換言前文節）」と呼び，また言い直しによって訂正された部分（下線で示した部分） を「換言後音節列 (換言後文節)」と呼ぶ。ささて, 言い直し表現の出現位置と種類について考え る. 換言前音節列は, 後で換言後音節列によって訂正される部分であるから，一種の誤りと見 なすことができ，それを削除すれば発話者の意図した文になると考えられる。このような観点 
から，会話テキストデータベース（A T R 音声翻訳通信研究所）に収録された「旅行に関する 対話」の対話例を対象に，言い直し表現が出現した位置を分類すると表 1 の通りとなる。この 表から, 換言前の音節列の約 $80 \%$ が正しい文の文節境界の位置に挿入された形になっているこ とが分かる.

表 1 言い直しの出現位置の傾向

\begin{tabular}{|c|c|c|}
\hline 出現位置 & 言い直し刘象の山現位㼭 & 割合 \\
\hline $\begin{array}{l}\text { 文節境界 } \\
\text { 位圆 }\end{array}$ & 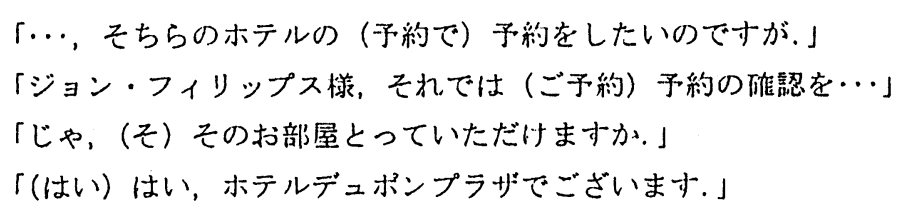 & $80.0 \%$ \\
\hline $\begin{array}{l}\text { 単語境界 } \\
\text { 位置 }\end{array}$ & 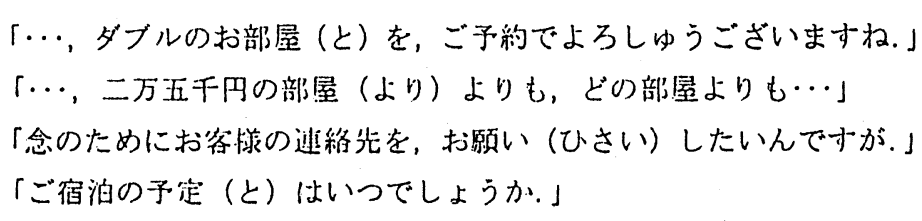 & $16.8 \%$ \\
\hline 集語内 & 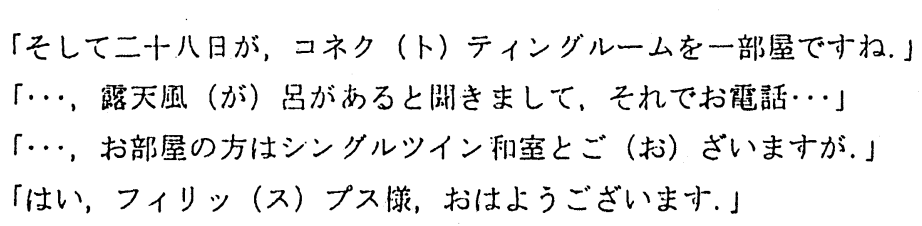 & $3.2 \%$ \\
\hline
\end{tabular}

次に，換言前音節列と換言後音節列が連続する場合について，言い直しのタイプを分類する と表 2 の結果を得る。この表から，言い直しの大半（表 2 の中の切り捨てタイプと置き換え夕 イプを除く約 $60 \%$ が該当）は，間違った表現をそれと同一内容を表す正しい表現への言い換え となっており, 繰り返しの構造を持っていることが分かる.

\section{2 言い直し表現抽出の方針}

前節の考察に従い，本論文では言い直し表現抽出の第 1 ステップとして，文節境界位置に現 れる繰り返しタイプの言い直し表現を対象にその抽出法を考える.

ところで, 抽出の対象とする言い直し表現は文節境界に現れることから, 言い直し表現自体 
は文節で，換言前表現の始点，終点は共に文節境界であると考えることができる。また，繰り 返しタイプの言い直しでは，換言前音節列と換言後音節列は連続しており，両者は類似した音

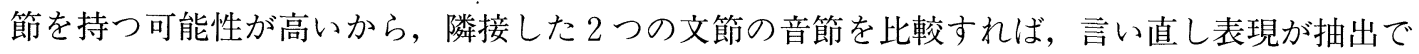
きると期待される。

表 2 言い直しパターンのタイプ

\begin{tabular}{|c|c|c|}
\hline タイプ & 䚈い值し刘象の梅造 & 割合 \\
\hline 繰り返し & 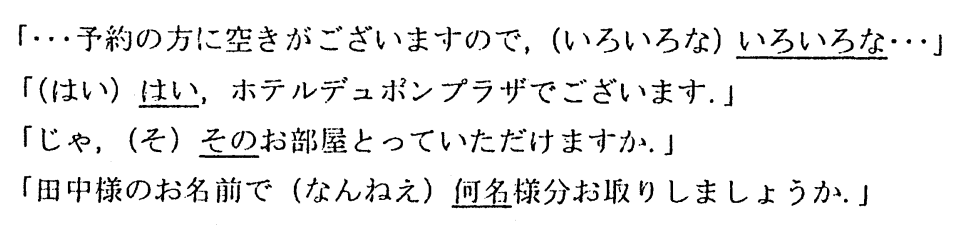 & $37.6 \%$ \\
\hline 切り唅て & 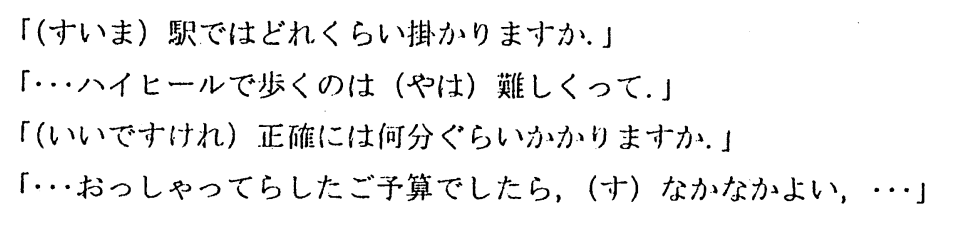 & $14.5 \%$ \\
\hline 置き換え & 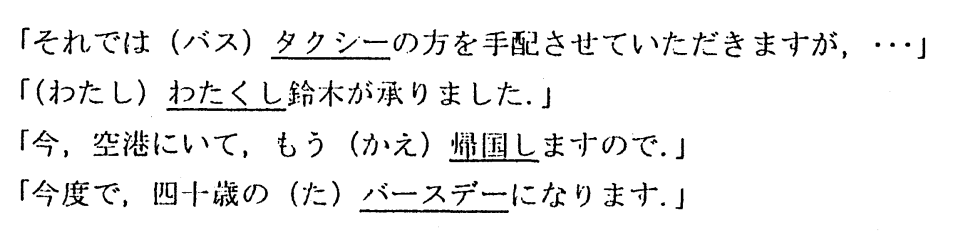 & $13.9 \%$ \\
\hline 付け加え & 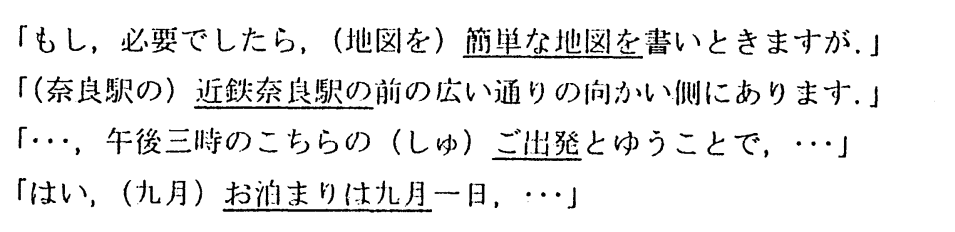 & $12.5 \%$ \\
\hline $\begin{array}{l}\text { 繰り返し } \\
\text { を伴う } \\
\text { 留き揷え }\end{array}$ & 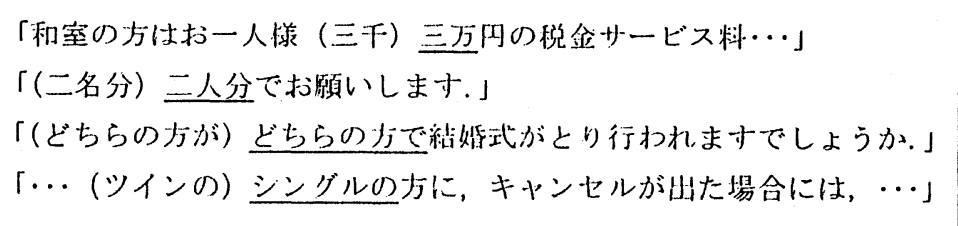 & $10.7 \%$ \\
\hline
\end{tabular}


以上から，ここでは，図 1 に示すように，以下の 2 つの段階に分けて言い直し表現を抽出 する。

第 1 段階：言い直しを含む音節文の文節境界を推定する。

第 2 段階 : 連接する2つの文節間で音節列を比較し，類似性の高い文節の組の前方の文節を 「換言前音節列」と判定する。

例文：(じゅうしちに）十七日の日は，ツインの部屋‥

ジュウシチニジュウシチニチノヒワツインノへヤ・..

（1）第 1 段階

文節境界推定処理

シュウシチニ

$$
\text { ジュウシチニチノ }
$$

ヒワ

ツインノ

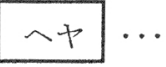

（2）第 2 段階
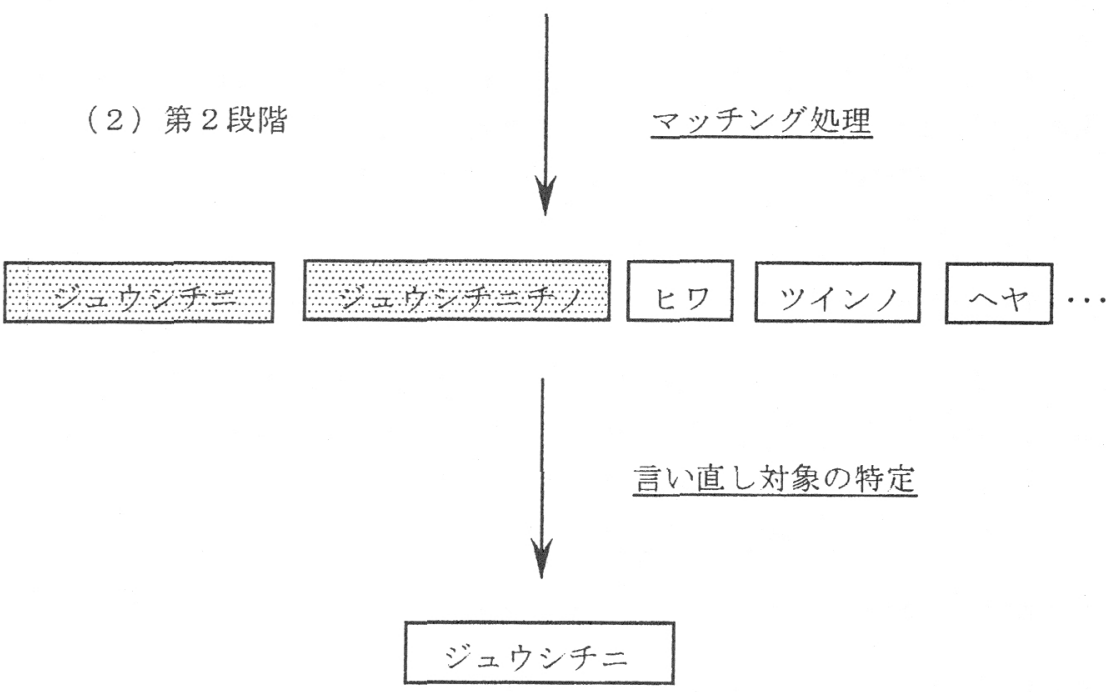

図 1 言い直し対象の検出の概要 


\section{3 言い直し表現の抽出法}

\section{1 言い直しを含む文節境界の推定}

\subsection{1 文節境界推定の基本的考え方}

言い直しを含む音節列の文節境界を推定する方法について考える，従来，べた書きされた日 本語かな文の文節境界を推定する方法として，マルコフ連鎖モデルを用いた方法 (荒木他 1997) が提案されている。この方法は, 図 2-(i)に示すように, 文節内では文字間の連鎖強度が高いこ とに着目して，文字連鎖確率值が落ち込むところを仮文節境界と推定するもので，具体的には， 文節境界は以下の 2 つの手順で決定される。

（1） かな文字列の前方から順にマルコフ連鎖確率を求め，連鎖確率がある閥值以下 (落ち 込み) となる文字を $x_{i}$ とする。( $\left(x_{i}\right.$ の直前に文節境界がある可能性が高い)

（2）文字 $x_{i}$ の直前に文節境界記号 $\mathrm{b}$ を挿入し，この記号と前方文字との連鎖確率を求め る。確率がある閥值以上 (立ち上がり) になったとき， b の位置を文節境界と判定する。

なお，(1)，(2) 共に，連鎖確率の評価では，正しく文節境界記号の挿入されたべた書きかな 文から得られた連鎖確率を使用する。

ところで，この方法は，文法的にも意味的にも正しい日本文を対象に提案された方法である. 言い直しを含む文では，換言前音節列の部分で発話の中断や言い誤りが起こっているため，仮 文節境界の判定に用いた連鎖確率の「落ち込み」や「立ち上がり」が必ずしもシャープには現 れない危険性があり，上記の方法を，言い直しを含む文にそのまま適用するのは適切でないと 考えられる。そこで，言い直し音節列の挿入された文節境界の性質について考えると以下のこ とが分かる (荒木, 池原, 橋本 1996).

まず，換言前音節列の始点に当たる文節境界では，その境界の直前の文字列は正しい文字列 であるので，前方向 (順方向)のマルコフ連鎖確率值が落ち込む位置を求めれば，その位置が換 言前音節列の始点となっている可能性が高い.

これに対して，換言前音節列の終点に当たる文節境界では，その境界の直前の文字列は言い 直し対象の一部 (言い誤りなど) であるので，前方向 (順方向)のマルコフ連鎖確率值が必ずしも 落ち込むとは限らない. しかし，その境界の後方の音節列は正しく言い直された音節列である ので，後方向 (逆方向) のマルコフ連鎖を使用すれば，連鎖確率の落ち込みによってその位置を 抽出できる可能性が高い.

以上から, 本論文では, 図 2-(iv) のように前方向 (順方向) と後方向 (逆方向) のマルコフ連 鎖確率值を組み合わせることによって文節境界を判定する. 

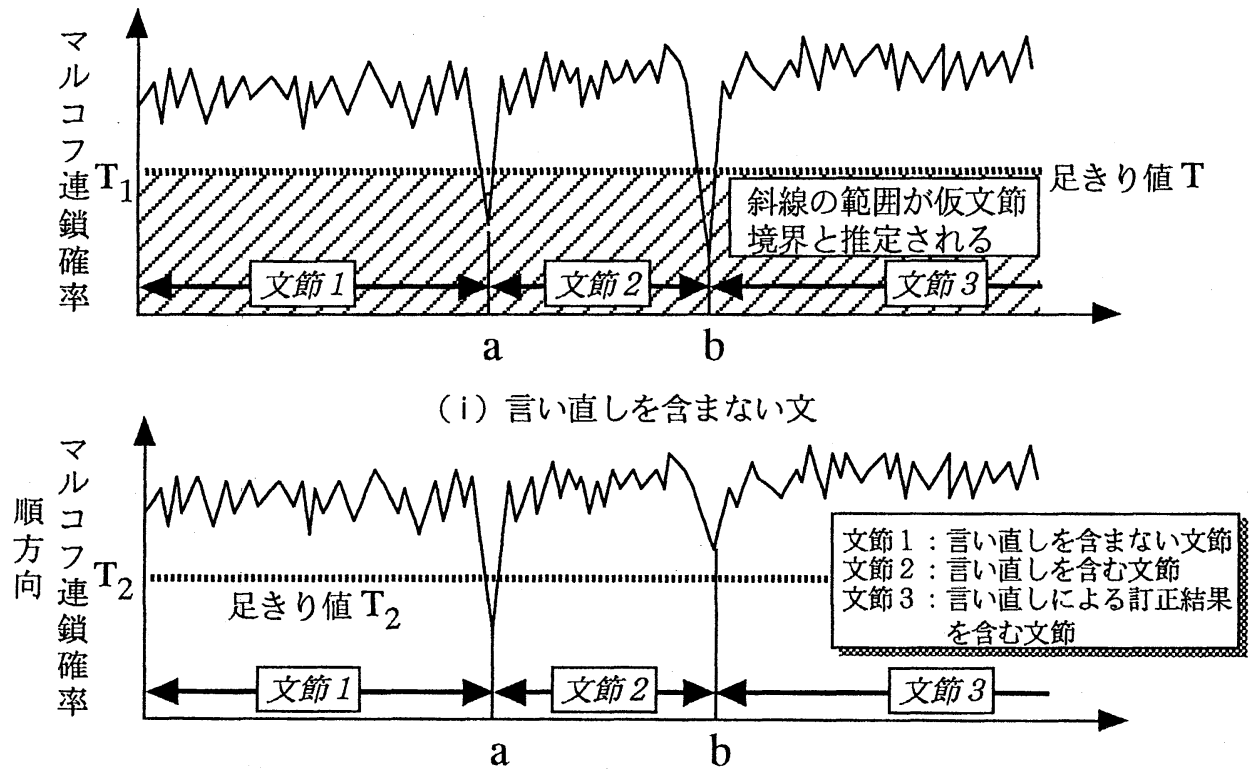

（ii）言い直しを含む文（順方向のマルコフ連鎖を用いるとき）

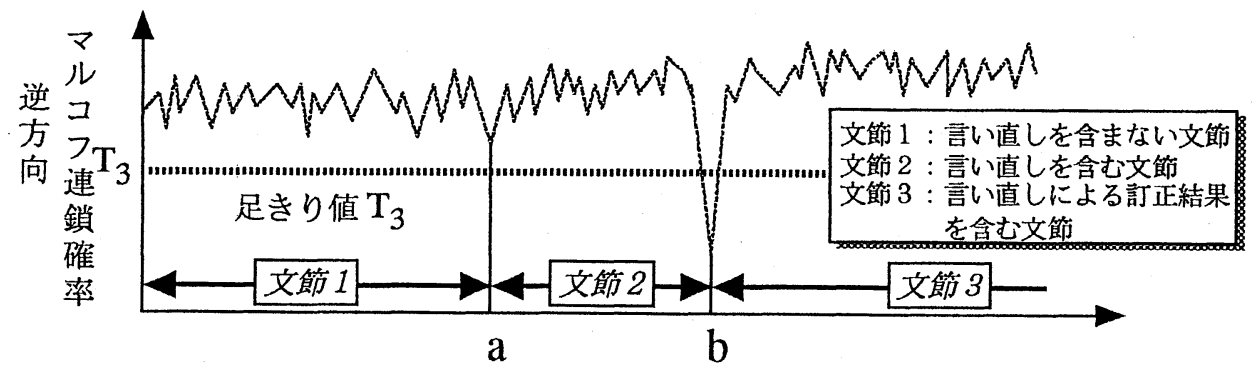

（iii）言い直しを含む文（逆方向のマルコフ連鎖を用るとき）

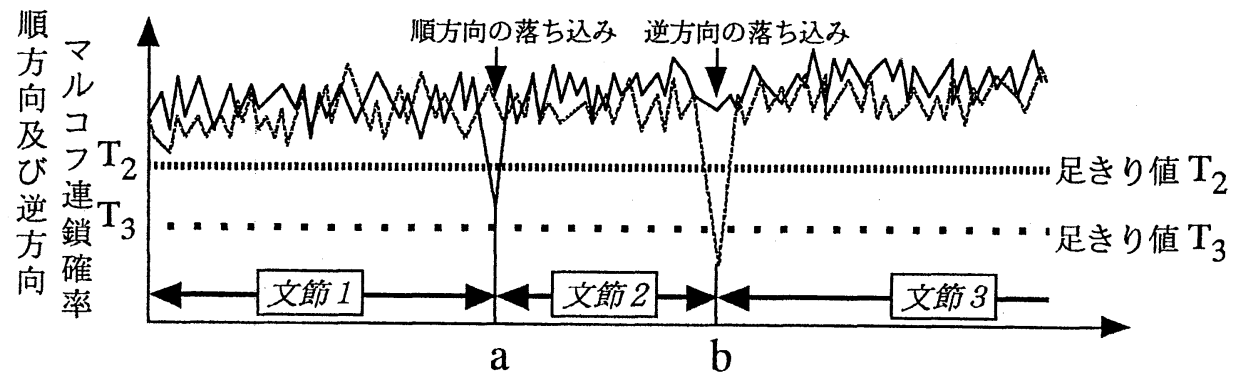

（iv）言い直しを含んだ文（順方向と逆方向の組み合わせによる）

図 2 言い直し列を含んだ音節文の仮文節境界の推定法 


\subsection{2 文節境界の推定}

文節境界の推定では，前方法，後方向のマルコフ連鎖モデルを使用することを述べたが，こ こではさらに，文節境界をまたがる文字連鎖の確率をも考慮し，3つの方法を考える．以下で は，(荒木他 1997) で用いられた下記の記号を用いて，各方法を定義する.

（1） FBL: 文節境界記号 $\mathrm{b}$ と前方文字との連鎖確率の「立ち上がり」を順方向に評価する 方法

（2） BBL: 文節境界記号 b と後方文字との連鎖確率の「立ち上がり」を逆方向に評価する 方法

（3） FL: 文節間をまたがる音節間の結合力 (「落ち込み」のみ) を順方向に評価する方法

（4） BL: 文節間をまたがる音節間の結合力（「落ち込み」のみ）を逆方向に評価する方法

なお，ここでは，マルコフ連鎖確率として 3 重マルコフモデルを用いる．また，以下では， 複数の方法を組み合わせて使用するときの文節境界の判定条件を記号「・( and )」,「+(or)」で 表す。

（1）＼cjkstart第一の方法：《単純な双方向型の推定》(FBL+BBL 法:図 3-(i))

連鎖確率の小さいところを抽出し，その位置に文節境界を表す記号 $\mathrm{b}$ を挿入したと き，記号 $\mathrm{b}$ についての双方向のマルコフ連鎖確率值の少なくともどちらか一つが，あ る閾値より大きくなるところを文節境界と推定する。

（2）第二の方法：《順方向挟み込み型を併用した双方向型の推定》 $(\mathrm{FL} ・(\mathrm{FBL}+\mathrm{BBL})$ 法: 図 3-(ii))

第一の方法に加えて，文節境界をまたがる文字間の連鎖確率を順方向に評価する.

（3）第三の方法：《双方向挟み込みを併用した双方向型の推定》 $(\mathrm{FL} ・ \mathrm{BL} ・(\mathrm{FBL}+\mathrm{BBL})$ 法:図 3-(iii)) 1

第一の方法に加えて，文節境界をまたがる文字間の連鎖確率を順方向と逆方法から評 価する.

\subsection{3 言い直し音節列の判定}

第 1 段階の方法で得られた文節境界のうち，任意の境界から始まる3つの連続した文節境界 を順に，第 1 ，第 2 ，第 3 文節境界と呼ぶ。連続した文節の類似性を判定するには，これらの文 節境界に挟まれた文字列を比較すればよいが，これらの文節境界は必ずしも正しいとは保証さ

13.1 .3 で後述するように，1つの文節境界だけを用いてマッチングを行う方式 1 の場合には, 文節境界の中で換言前音 節列の始点に当たる文節境界の検出精度を高くすることが必要となる，その場合には，換言前音節列は一種の誤り文字 列と見なすことができるから, 逆方向のマルコフ連鎖モデルとして B B Lを用いる効果は少ないが, B Lを用いる効果 は大きい（誤り文字列の場合はB Lが落ち込む）と考えられることから，FL・BL・(FBL+BBL) 法よりも FL・BL・ FBL 法が有効と考えられる．両者の比較については，5．の実験結果で議論される. 


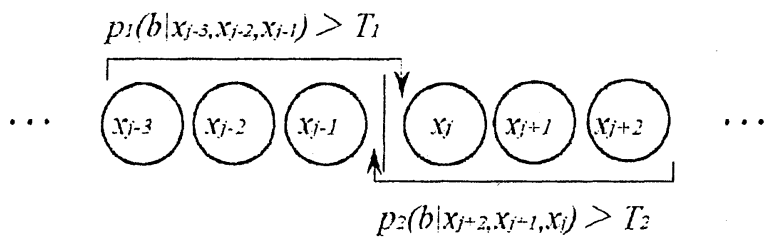

（i）第一の方法《単純な欢方向型の推定》( FBL+BBL法)

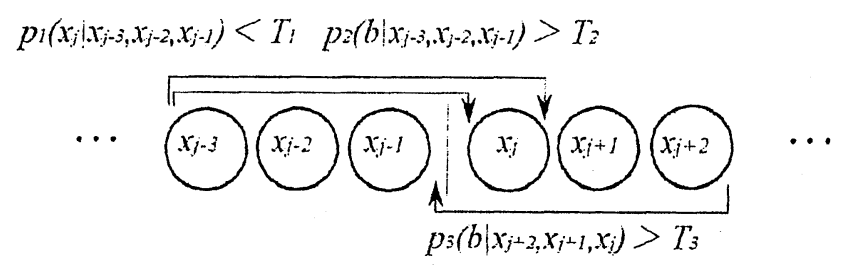

(ii）第二の方法《順方向挟み込み型を併用した 双方向型の推定》(FL・(FBL+BBL) 法)

$p_{i}\left(x_{i} \mid x_{j-3}, x_{j-2,2}, x_{j-1}\right)<T_{1} \quad p_{2}\left(b \mid x_{j-3,}, x_{j-2}, x_{j-1}\right)>T_{2}$

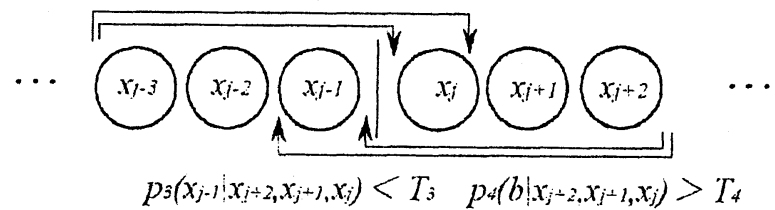

（iii）第三の方法 《双方向挟み迄み型を併用した 欢方向型の推定 (FL·BL· $(F B L+B B L)$ 法)

図 3 マルコフモデルによる文節境界の推定方法

れない. 特に，3つの文節境界が共にすべて正しい確率は，一つの境界が正しい場合よりも低 下するから，なるべく少ない数の境界を使用して言い直し表現を抽出できるのが望ましい. し かし，逆に，使用できる文節境界が少ない場合は，文節間の類似性判定の精度が低下する恐れ がある。

これらの点を考虑して，ここでは，文節間の類似性を判定する方法（マッチング法）として， 以下の 3 つの方法を考える. 
（1） 方式 1：1つの文節境界だけを使用する方法

（2）方式 2：連続した 2 つの文節境界を使用する方法

（3）方式 3：連続した 3 つの文節境界を使用する方法

以下，これらの 3 つの方法の詳細を述べる。まず，隣接する任意の 2 つの文節候補をそれ ぞれ， $B_{1}=x_{1} x_{2} \cdots x_{m}$ ，および， $B_{2}=x_{m+1} x_{m+2} \cdots x_{m+n}$ とする.

\section{【方式 1 のマッチング方法】}

（1）与えられた文節の先頭を始点として，長さ $l$ 文字 ( $l$ は平均文節長の $2 \sim 3$ 倍程度) の 音節列 $X=x_{1} x_{2} \cdots x_{l}$ （但し， $X$ の中に先頭文字 $x_{1}$ と等しい文字 $x_{i}$ が存在する。す なわち, $\left.x_{1}=x_{i}\right)$ を取り出す.

（2） $x_{1}, x_{2}, \cdots, x_{l}$ を図 4 のように横と縦にならべたマトリックスを考え， $x_{1}=x_{i}$ となる $x_{i}$ の位置 $i($ 但し, $2 \leq i \leq l)$ を換言後文節の開始点とする.

(3) 換言前文節候補の $i-1$ 個の音節列 $x_{1} x_{2} \cdots x_{i-1}$ の少なくとも $j=(i-1)-k$ 個の $j$ (ここで, $1 \leq j \leq i-1)$ に対して, 式 $x_{j}=x_{j+i-1}$ が成り立つ時, $i-1$ 個の音節列 $x_{1} x_{2} \cdots x_{i-1}$ を換言前音節列として抽出する.ここで，kはハミング距離であり，実 験的に最適值を定める.

\section{【方式 2 のマッチング法】}

（1） 2 つの文節候補 $B_{1}$ と $B_{2}$ において， $B_{1}$ を換言前文節候補とし， $B_{2}$ の文字列の中から その部分列として， $B_{1}$ の文節長 $m$ と同じ長さの音節列 $B_{2}=x_{m+1} x_{m+2} \cdots x_{2 m}$ を取 り出す。

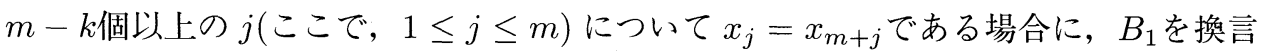
前音節列とする。ただし， $x_{j}$ と $x_{m+j}$ はそれぞれ文節 $B_{1}$ と $B_{2}$ の中の $j$ 番目の音節を 表す。

\section{【方式 3 のマッチング法】}

第 1 , 第 2 , および第 3 の文節境界によって決定される音節列 $B_{1}$ おび， $B_{2}$ の組に 対して, 少なくとも $m-k$ 個の $j$ (但し, $j$ はと $n$ の中で小さい方の值に対して, $1 \leq j \leq m($ または $n))$ について $x_{j}=x_{m+j}$ となる場合に， $B_{1}$ を換言前音節列とする.

\section{4 言い直し表現の抽出精度の推定}

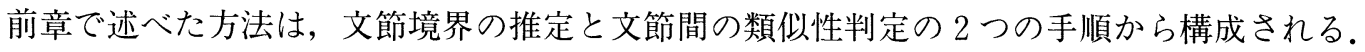
そこで，本章では，文節境界の推定精度（適合率 $P_{b}$ と再現率 $R_{b}$ ），及び，文節間の類似性の推 


$$
\begin{array}{ll}
\mathrm{x}_{1}=\mathrm{x}_{\mathrm{i}} \text { の点を開始点とする } & \exists \mathrm{i},\left(\mathrm{x}_{1}=\mathrm{x}_{\mathrm{i}}, \mathrm{x}_{2}=\mathrm{x}_{\mathrm{i}+1}, \cdots, \mathrm{x}_{\mathrm{i}-1}=\mathrm{x}_{2 \mathrm{i}-1}\right) \\
& \text { のうち } \mathrm{i}-2 \text { 個以上において成立する }
\end{array}
$$

\begin{tabular}{|c|c|c|c|c|c|c|c|c|c|c|c|}
\hline & $x_{1}$ & $x_{2}$ & $\ldots$ & $x_{i-1}$ & $x_{i}$ & $x_{i+1}$ & $\cdots$ & $x_{2 i-1}$ & $x_{2 i}$ & $\cdots$ & $x_{1}$ \\
\hline $\mathrm{x}_{1}$ & 7 & $x$ & $x$ & $\times 1$ & 0 & $\times$ & $x$ & $x$ & $x$ & $x$ & $x$ \\
\hline$x_{2}$ & & 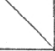 & $x$ & $x$ & $x$ & 0 & $x$ & $x$ & $x$ & $x$ & $x$ \\
\hline$\vdots$ & & & & $x$ & $x$ & $x$ & $\because$ & $\times$ & $x$ & $x$ & $x$ \\
\hline $\mathrm{x}_{\mathrm{i}-1}$ & & & & & $x$ & $x$ & $x$ & 0 & $x$ & $x$ & $x$ \\
\hline$x_{i}$ & & & & & & $x$ & $x$ & $X$ & $x$ & $x$ & $x$ \\
\hline$x_{i+1}$ & & & & & & & $x$ & $x$ & $x$ & $x$ & $x$ \\
\hline$\vdots$ & & & & & & & 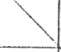 & $x$ & $x$ & $x$ & $x$ \\
\hline$x_{2 i-1}$ & & & & 不覀 & & & & 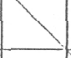 & $x$ & $x$ & $x$ \\
\hline$x_{2 i}$ & & & & & & & & & & $x$ & $x$ \\
\hline$\vdots$ & & & & & & & & & & & $x$ \\
\hline $\mathrm{x}_{1}$ & & & & & & & & & & & \\
\hline
\end{tabular}

(a) 第1のマッチングち式

隣接した 2 文節の筸節マッチング 米設定の文節

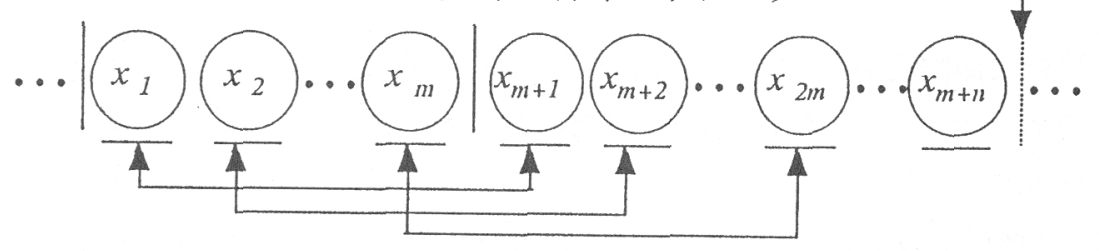

$x_{i, j}:$ 文中の $\mathrm{i}$ 番面の文節の $\mathrm{j}$ 番目の音節

(b) 第 2 のッチングカ式

隣接した 2 文節の音節マッチング

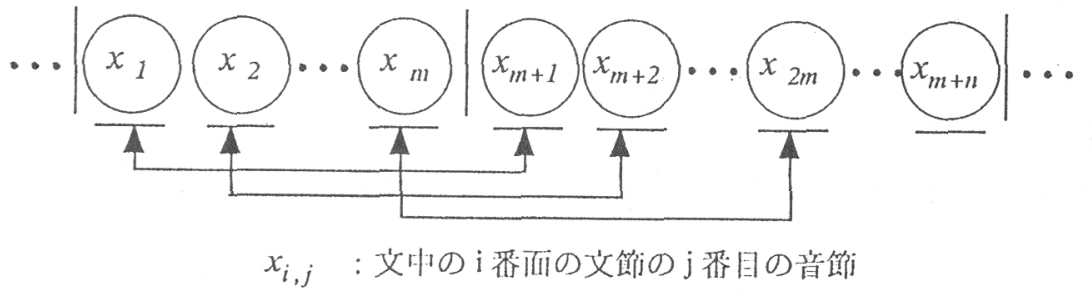

八ミング距燋がm-1以下のマッチング法 : 少なくとも1䇴所で一致

(c) 符3のマッチング方式

図 4 マッチングによる言い直し対象の検出方法 
定精度（適合率 $P_{m}$ と再現率 $R_{m}$ ）が与えられた時, 最終的に抽出される言い直し表現の抽出精 度（適合率 $P_{t}$ と再現率 $R_{t}$ ）を推定する方法について考える。

\section{1 文節抽出精度の推定}

文節境界推定の結果から，マッチングの 3 方式に必要な文節がどれだけ正確に抽出できるか 考える.

\section{（1）任意の文節の先頭位置が正しい確率}

まず，実験標本に含まれている正しい文節境界の数を $n$ ，文節境界の候補として検出した境 界の数を $n_{1}$, そのうち正しい文節境界の数を $n_{0}$ とすると, 推定された文節境界の適合率 $P_{b}$, 再現率 $R_{b}$ は，それぞれ，

$$
P_{b}=n_{0} / n_{1}, R_{b}=n_{0} / n
$$

であるから，正しく推定された文節境界の数を $N_{1 \max }$ と置くと， $N_{1 \max }$ は $n_{0}$ に等しく,

$$
N_{1 \max }=n_{0}=n R_{b}
$$

\section{( 2 ) 正しく取り出される文節の数}

推定された文節境界から，どれだけの数の文節が正しく取り出せるかを考える．正しい文節

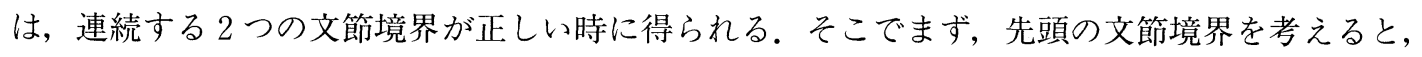
(1) から, そのような境界は, $n_{0}$ 個得られる。次に, これらの $n_{0}$ 個の境界に続く文節境界がど れだけ正しく決定されているかを考える，但し，ここでは， $n, n_{0}, n_{1}$ はいずれも 1 より分大 きい值とする，ある正しく決定された文節境界 (始点) の後に初めて現れる文節境界としては,

$$
\text { 正しく文節境界として検出されたもの }\left(n_{0}\right)
$$

$$
\begin{aligned}
& \text { 誤って文節境界と判定されたもの }\left(n_{1}-n_{0}\right) \\
& \text { 見過ごされてしまったもの }\left(n-n_{0}\right)
\end{aligned}
$$

の 3 種が考えられる. 全体では, $n_{0}+\left(n_{1}-n_{0}\right)+\left(n-n_{0}\right)=n+n_{1}-n_{0}$ 通りの可能性がある が, このうち (1) の場合のみ正しい文節が得られる.どの可能性も文節開始点と独立に現れる と仮定すると，(1) が現れる確率は $n_{0} /\left(n+n_{1}-n_{0}\right)$ である. 以上から，正しく抽出された文節 の数は, $N_{2 \max }$ は,

$$
N_{2 \max }=n_{0} \times n_{0} /\left(n+n_{1}-n_{0}\right)
$$

と推定される。ここで，(1) および (2) 式を用いて書き替えると,

$$
N_{2 \max }=n \times R_{b} \times \gamma
$$

但し $\gamma=P_{b} R_{b} /\left(R_{b}+P_{b}-R_{b} P_{b}\right)$. 


\section{( 3 ) 連続して正しく取り出せる文節の組の数}

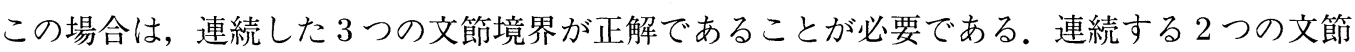
境界が正しい文節境界の組みの数は (3) 式で与えられるから，連続した 3 つの文節境界が正解 となる組の数 $N_{3 \max }$ は，(2) と同様の議論によって， $N_{2 \max }$ の $\gamma$ 倍となるから,

$$
N_{3 \max }=n \times R_{b} \times \gamma^{2}
$$

\section{2 言い直し表現の抽出精度の推定}

\section{（1）言い直し表現の総合的な抽出精度}

文節間の音節類似性を判定するマッチング処理で，言い直し表現が正しく言い直しとして抽 出できるのは，正しい文節境界を持つ文節候補の中からのみと考えられる．これに対して，誤っ た言い直し表現は，文節境界が正しい場合からも，また，文節境界が誤った場合からも抽出さ れる。そこで，正しい文節境界を持つ文節に含まれる言い直し表現が，正しく言い直しと判定 される割合を $\alpha$ と，言い直しでない文節を間違って言い直しと判定する割合を $\beta$ とするまた， 文節境界推定実験で得られた文節の数を $N$ ，その中の正しい文節境界を持つ文節に含まれる言 い直し表現の数を $M$ とする。この時，マッチング実験において正しく言い直しと判定されるも のは, $\alpha M$ 件, 詔って言い直しと判定されるものは, $\beta(N-M)$ 件であるから, 総合的な（第 1 段階と第 2 段階を組み合わせたときの）言い直し表現の抽出精度（適合率 $P_{t}$ と再現率 $R_{t}$ ） は,

$$
\begin{gathered}
P_{t}=\alpha M /\{\alpha M+\beta(N-M)\} \\
R_{t}=\alpha M / m
\end{gathered}
$$

となる，但し， $m$ は標本全体に含まれる言い直し文節の数を示す。ここで， $m$ は既知としてよ いから， $N, M, \alpha, \beta$ 4 つのパラメータの值が分かれば， $P_{t}, R_{t}$ は計算できる。そこで，以下 では, これらの值を求める。

\section{( 2 ）文節数と光の中の換言文節数 (N と $\mathrm{M}$ )}

ここで，第 1 段階の文節境界の推定で得られる言い直し文節候補の数 $N$ とその中に含まれ る言い直し表現の数 $M$ を考える，Nは，3つのマッチング方式いずれの場合も共通で,

$$
N=n_{1}=n R_{b} / P_{b}
$$

次に, 標本内の文節のうち, 言い直し表現の含まれる割合を $a(=m / n)$ とする. 第 2 段階で は, 第 1 段階で正しく抽出された文節 $\left(N_{1 \max }, N_{2 \max }, N_{3 \max }\right)$ の中に含まれた言い直しのみが 抽出の可能性を持つ.そこで，第 1 段階で抽出された文節も同じ割合で言い直し文節を含むと 
仮定すれば，その数 $M$ は，

$$
M=a \times N_{\text {imax }}(\text { 但し }, i=1,2,3)
$$

となる。

\section{( 3 ) 言い直し判定の確率 $(\alpha$ と $\beta)$}

ここで，すべての文節境界 $N$ が正しい場合を考え，正しい文節境界を持つ $N$ 個の文節の中 に， $m$ 個の言い直し表現が含まれていたとする。また，この標本に対して文節のマッチング処 理によって， $m_{1}$ 個の文節が言い直しと判定され，そのうち正しく判定されたものは $m_{t}$ 個だっ たとすると，マッチングの精度（適合率 $P_{m}$ と再現率 $R_{m}$ ） は,

$$
P_{m}=m_{t} / m_{1}, R_{m}=m_{t} / m
$$

で与えられる。 この時， $\alpha$ は, 定義により， $\alpha=R_{m}$ である. また， $\beta$ は, 以下のように求めら れる。すなわち，言い直しでない文節数は $N-m$ 件存在するのに対して，このうちの $m_{1}-m_{t}$ 件を言い直しと判定したことになるから， $\beta=\left(m_{1}-m_{t}\right) /(N-m)$. ここで，全文節 $N$ に含 まれる言い直し文節 $m$ の割合を $a(=m / N)$ とおき，(10) 式を使用すると， $\beta$ は,

$$
\beta=\frac{\alpha R_{m}\left(1-P_{m}\right)}{P_{m}(1-\alpha)}
$$

以上で, 第 1 段階と第 2 段階の方法の精度（それぞれ， $P_{b}, R_{b}$ および $P_{m}, R_{m}$ ) が分かれば， それを結合した総合的な抽出精度 $\left(P_{t}, R_{t}\right)$ が推定できる.

\section{5 実験結果と考察}

\section{1 実験の条件}

本実験では，以下に示すような入力文とマルコフ連鎖確率辞書を用いた。

(1) 実験入力文

(i) 文の内容：旅行に関する会話

(ii) 文の表記 : 文音節列

(iii) 総文数：100 文（標本外, 文節境界位置に出現する単純な繰り返しタイプの言 い直しが少なくとも一つ存在するもの)

（iv）総文節境界数：346 境界（うち, 言い直し対象の始点 106, 終点 106) 
（2）マルコフ連鎖確率辞書の統計データ

(i) データの内容：旅行に関する会話

（ii） デー夕の表記：文節音節列（空白記号付き，言い直しは含まない）

(a) 総文節数: 27,120 文節

（b） 総音節数：236,705 音節（空白記号を除くと 155,345 音節）

(3) マルコフ連鎖確率辞書のタイプ

種類：文節マルコフ連鎖確率

次数: 4 次 $(3$ 重)

方向のタイプ: 順方向と逆方向

\section{2 文節境界推定実験の結果}

3.1 節で述べた 3 つの文節境界推定法について, 閾值を変化させた時の再現率と適合率の値 を図 5 に示す。この四と 4 章の結果 ((2) 式, (3) 式, (5) 式) を用いれば, それぞれのマッチン グの方法に適したように， $N_{\text {imax }}$ を最大とするような $P_{b} ， R_{b}$ を選択することができる．その結 果を求めると，いずれの場合も，その值は $P_{b}$ と $R_{b}$ の調和平均を最大とする值の近傍（土1\%以 内）にあるため, ここでは， $P_{b} と R_{b}$ の調和平均が最大となる場合について，各方式の精度を表 3 に示す. また，各推定法によって推定された文節境界の例を表 4 に示す。これより以下のこ とが分かる。

（1）提案した 3 つ文節境界推定法のうち，第 3 の方法が最も優れており，言い直し表現 を含まない場合と同程度の精度（適合率 $88.0 \%$, 再現率 $89.6 \%$ ）が得られる.

（2）換言前音節列の始点の再現率 $(85.8 \%)^{2}$ は，全体の文節境界の再現率 $(89.6 \%)$ より，約 $4 \%$ 低い.またその終点の再現率 $(77.4 \%)$ はさらに約 $8 \%$ 低い.

\section{3 文節マッチング法の実験結果}

文節境界精度がすべて正しい場合について，3.2 で述べた 3 種のマッチング方法を用いて言 い直し音節列抽出実験を行なった。その際，マッチングで用いたハミング距離 $k$ マついては, $k=0$ から $m-1$ の範囲で実験を行い, $P_{m}, R_{m}$ が共に大きくなる值（今回の実験では， $k=1$ ) に設定した．実験の結果を表 5 の (2) の欄に示す。また， 3 通りのマッチング方式による言い 直し音節列の抽出結果の例を表 6 に示す. 表 5 の (2)の欄から以下の観察が得られる.

2 換言前音節列の始点の再現率だけに限って言えば，第 3 の方法よりも FL・BL・FBL 法を用いた方が，換言前音節列の 始点の再現率は，約 $5 \%$ 高い値 $(90.6 \%)$ が得られる (図 6 参照). 


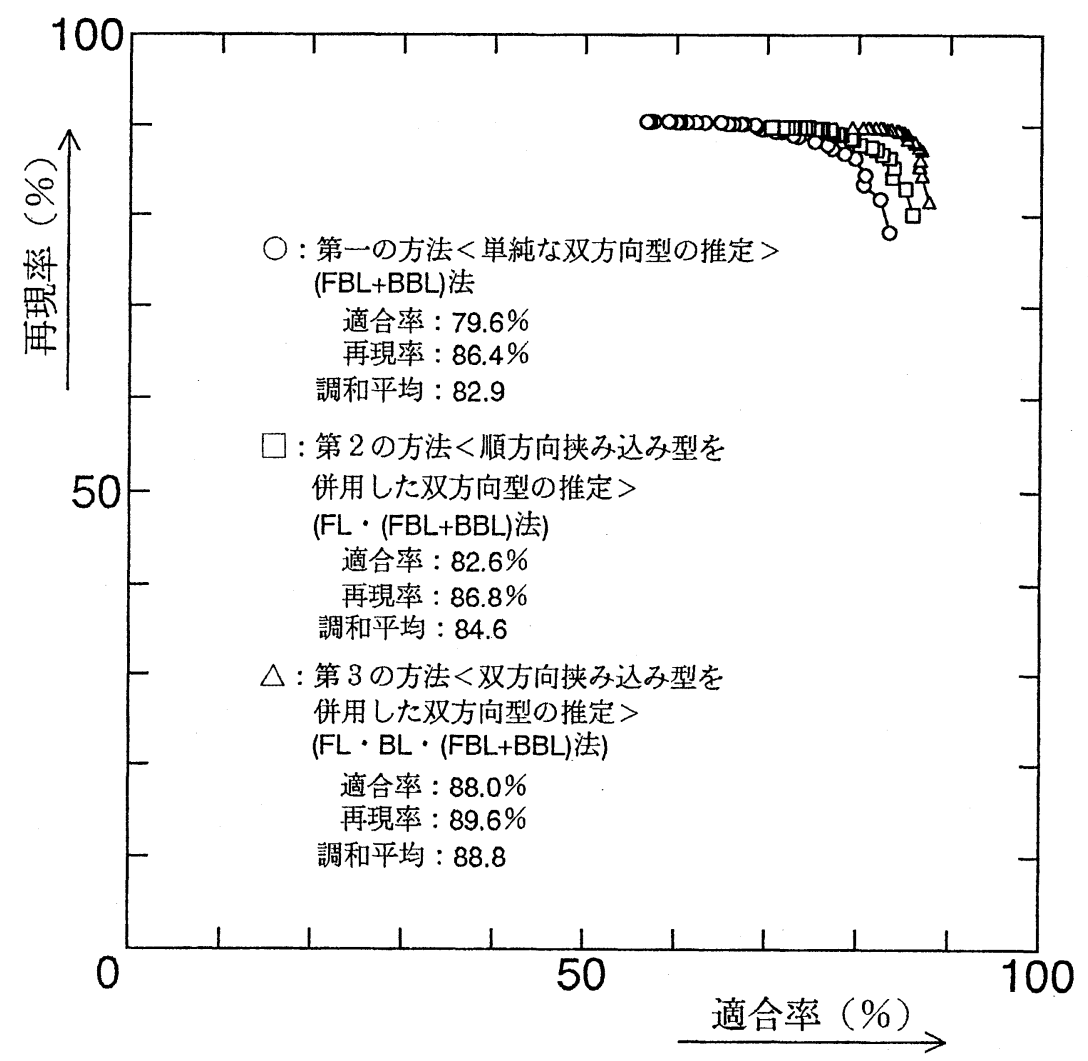

図 5 言い直しを考虑した文節境界の推定結果

（1）方式 2，3の適合率 (共に約 $99 \%$ ) は，方式 1（約 86\%）に比べて $10 \%$ 以上，適合率 が高い.

（2）逆に，方式 2，3の再現率 (84〜 85\%) は，方式 1 (約 89\%) に比べて 4〜 5\%低い.

このうちの (1) から，第 2 の文節境界が正しく決定できることは，マッチングの精度を上げ る上で有効であるが，第 3 の文節境界の情報はあまり価值を持たないことが推定される．また， (2) の差は，方式 1 のマチング法では，方式 2 ，方式 3 のマッチング法よりも甘い基準で言い 直しを判定していることから生じたものと考えられる.

\section{4 総合実験結果と推定値の比較}

4 章の方法を用いて，第 1 段階の実験結果（5.2 節）と第 2 段階の実験結果（5.3 節）から， 総合的な言い直し表現の抽出精度を推定した結果を表 5 に示す。これと比較して，実際に第 1 段階の文節境界推定の方法と（第 3 の方法）と第 2 段階のマッチング処理を組み合わせて行っ 
表 33 つの方法による文節境界の推定結果の比較

\begin{tabular}{|c|c|c|c|c|}
\hline 推定方法 & & 適合率 (\%) & 再現率 (\%) & 調和平均 \\
\hline \multirow{3}{*}{$\begin{array}{l}\text { 第一の方法： } \\
\text { 《単純な双方向型の推定》 } \\
\text { (FBL+BBL法) }\end{array}$} & 仮文節境界 & $\begin{array}{c}633 / 795 \\
79.6 \\
\end{array}$ & $\begin{array}{c}633 / 733 \\
86.4 \\
\end{array}$ & 82.9 \\
\hline & 言い直し始点 & & $\begin{array}{c}75 / 106 * \\
70.8 \text { (注) }\end{array}$ & 16.6 \\
\hline & 言い直し終点 & & $\begin{array}{c}80 / 106 * \\
75.5\end{array}$ & 17.8 \\
\hline \multirow{3}{*}{$\begin{array}{l}\text { 第二の方法 : } \\
\text { 〈順方向挟み込み型を併用した } \\
\text { 双方向型の推定〉 } \\
\text { (FL·(FBL+BBL法) }\end{array}$} & 仮文節境界 & $\begin{array}{c}636 / 770 \\
82.6 \\
\end{array}$ & $\begin{array}{c}636 / 733 \\
86.8 \\
\end{array}$ & 84.6 \\
\hline & 言い直し始点 & & $\begin{array}{c}80 / 106 \\
75.5\end{array}$ & 18.3 \\
\hline & 言い直し終点 & & $\begin{array}{c}79 / 106 \\
74.5\end{array} *$ & 18.0 \\
\hline \multirow{3}{*}{$\begin{array}{l}\text { 第三の方法: } \\
\text { 〈双方向挟み込み型を併用した } \\
\text { 双方向型の推定〉 } \\
(\mathrm{FL} \cdot \mathrm{BL} \cdot(\mathrm{FBL}+\mathrm{BBL} \text { 法)) }\end{array}$} & 仮文節境界 & $\begin{array}{c}657 / 747 \\
88.0\end{array}$ & $\begin{array}{c}657 / 733 \\
89.6\end{array}$ & 88.8 \\
\hline & 言い直し始点 & & $\begin{array}{c}91 / 106 \\
85.8\end{array} *$ & 21.3 \\
\hline & 言い直し終点 & & $\begin{array}{c}82 / 106 \\
77.4\end{array} *$ & 19.2 \\
\hline
\end{tabular}

（注）すべての言い直し境界（始点、終点）のうちで、 正しく検出された言い直し境界の割合

表 4 文節境界の推定結果の例の一覧

\begin{tabular}{|c|c|}
\hline 正 & $\begin{array}{l}\text { ハイ オマチアワセ) バショガ ビジュツカントイウ } \\
\text { (コト) コトデゴザイマスネ }\end{array}$ \\
\hline $\begin{array}{l}\text { 第1の方法 } \\
\text { FBL+BBL法 }\end{array}$ & $\begin{array}{l}\text { ハイノオ/イチアワセノノバショガノビジニツカントイウノ } \\
\text { コトノコトデヨ゙ザイマスネ }\end{array}$ \\
\hline $\begin{array}{c}\text { 第2の方法 } \\
\mathrm{FL} \cdot(\mathrm{FBL}+\mathrm{BBL}) \text { 法 }\end{array}$ & $\begin{array}{l}\text { ハイノオ/ハチアりセノノバショ犺ノビジュツカン//トイウ } \\
\text { ノコトノコトデゴザイマスネ }\end{array}$ \\
\hline $\begin{array}{c}\text { 第3の方法 } \\
\mathrm{FL} \cdot \mathrm{BL} \cdot(\mathrm{FBL}+\mathrm{BBL}) \text { 法 }\end{array}$ & $\begin{array}{l}\text { ハイノオマチアワセノノバショガノビジュツカントイウノコ } \\
\text { トノコトデゴザイマスネ }\end{array}$ \\
\hline
\end{tabular}

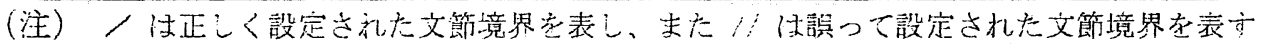

た言い直し音節列抽出実験の結果を同じ表に示す。また，総合的な適合率と再現率の関係を図 6 に示す。これらの結果から以下のことが分かる。

\section{<実験値の特性 $>$}

（1） 方式 1 は，他の方式と比べて再現率が高い $\left(R_{t}=75.5 \%\right)$ のに対し，方式 2 や方式 3 は逆に適合率が高い $\left(P_{t}=93.5 \sim 94.9 \%\right)$.

(2) 万式 2 と 3 には，大差は認められない. 
表 5 文節境界抽出精度，マッチング精度及び言い直し音節検出精度の計算值と実験値

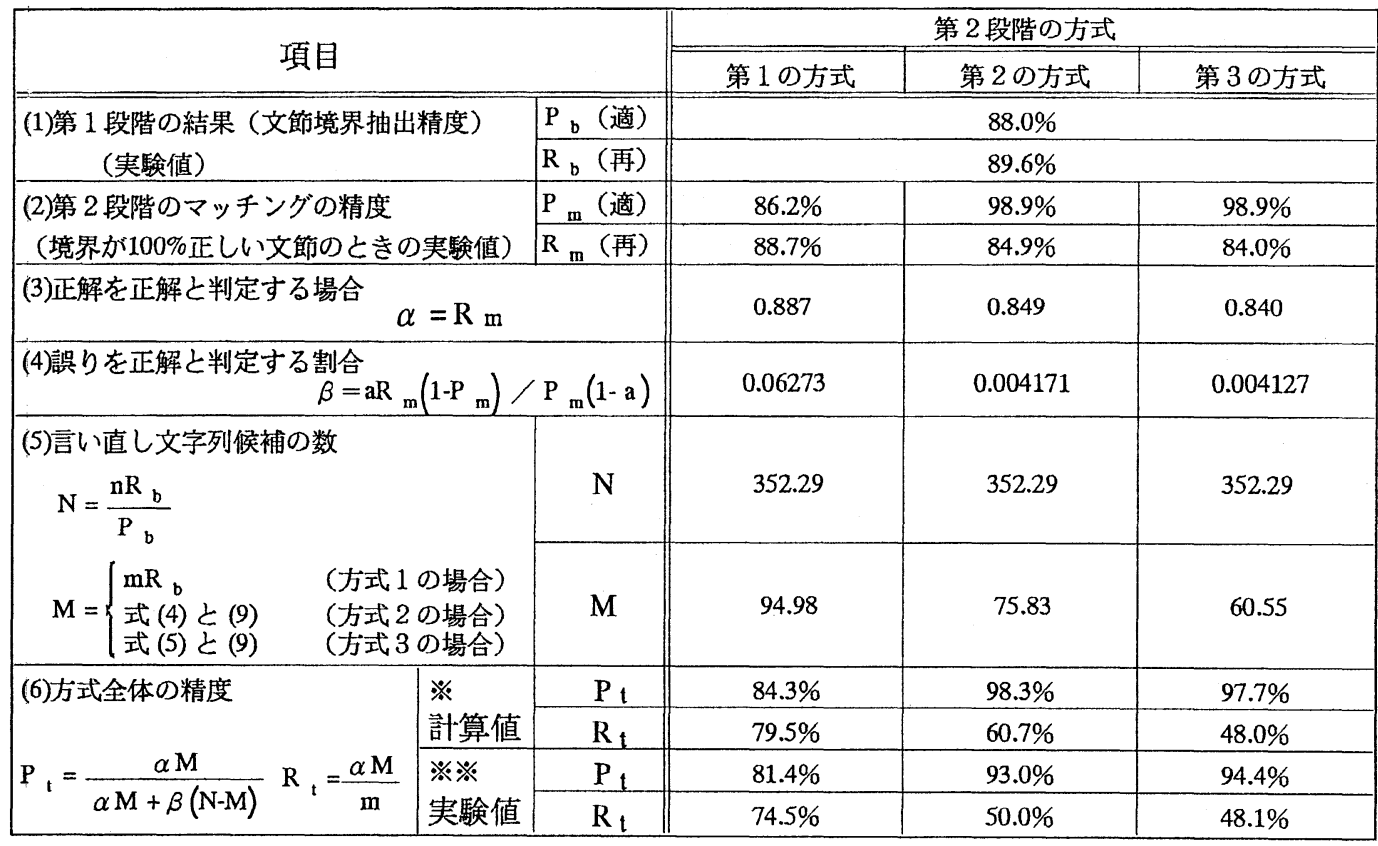

実験パラメータ

標本内文節数 $\quad \mathrm{n}=346$ 文節

※ (2)(3)の結果を用いて計算した結果

そのうち言い直し文節数 $\mathrm{m}=106$ 文節

(従って $a=m / n=30.64 \%$ )

(1) は 5.3 節の実験結果から予測された通りである。また $(2)$ も，第 1 文節境界に比べて第 2 文節境界の推定が低いこと，第 3 文節境界の情報はあまり影響しないことから予測された通 りといえる.

\section{<推定値との比較 $>$}

（1） 総合実験における精度 $\left(P_{t}, R_{t}\right)$ は, 一部を除いて, 実験值が推定值より，3〜6\%低 くなっている.

これは，推定值の計算では「言い直し文節とその他の正しい文節の境界が同じ精 度で決定できる」と仮定していたが，実際の言い直し表現では，「言い直し文節の境界 はその他の文節境界より決定しにくい」ことが原因と考えられる.上記の差が方式 1 に比べて方式 2 で顕著であるのは，特に，第 2 文節境界決定が困難であるためと思わ れる。

（2）方式 3 では， $R_{t}$ の值は，(1) とは逆に実験值の方が推定值よりも高い.

最終的に抽出される言い直し表現は，換言前文節（第 1 , 第 2 文節境界で囲まれ 
表 63 通りの方式による言い直し音節列抽出結果の例

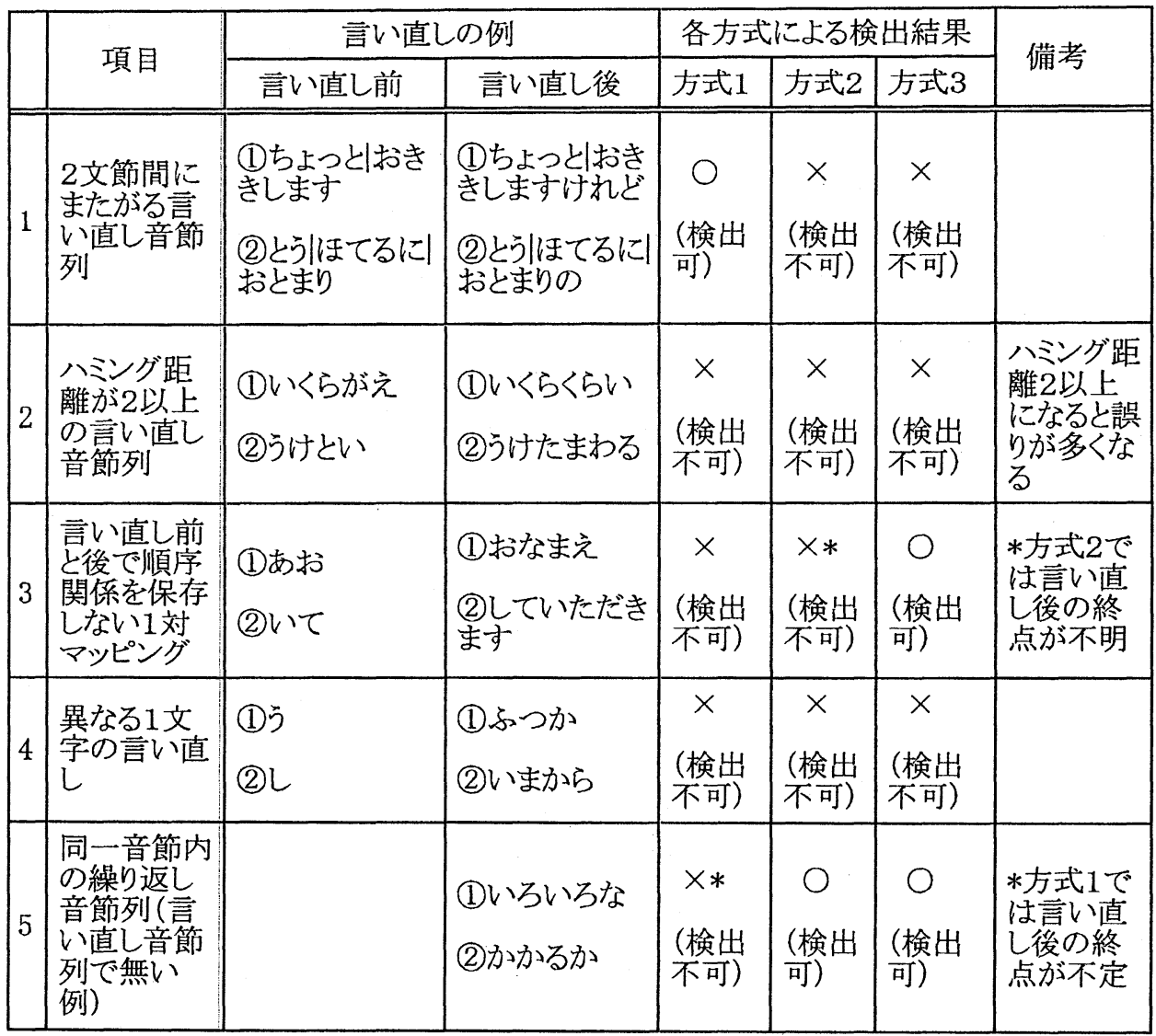

た範囲）であり，換言後文節は抽出されないこと，従って，第 1 段階の文節境界の推 定で，第 2 文節が正しく判定されなかった場合でも，言い直し表現が抽出できること があるためと考えられる。

（3）適合率 $P_{t}$ は，方式 3 が最も高く，方式 1 が最も低いと考えられるが，推定值は，方 式 2 と方式 3 でこの関係が逆転している.

この理由は以下の通りと考えられる．すなわち，方式 3 は，方式 2 に比べて第 1 段階で得られた文節候補中に含まれる言い直し文節候補が少ない。このため，言い直 し文節と正しく判定できる文節は限られている。 これに対して，正しい文節境界を持 たない文節候補が多いため，第 2 段階のマッチングでは，より多くの正しくない文節 が言い直しと判定される（すなわちごみが増える）ためと考えられる.

以上の換言前音節列の抽出結果は, 各方式とも第 1 段階において, 5.2 で述べた第 3 の方法を 
用いて文節境界を推定していた。しかし，マッチング方式 1 の場合には，文節境界の中で特に， 換言前音節列の始点に当たる文節境界の精度が高いことが要求されることから，FL・BL・FBL 法を用いた方が換言前音節列の抽出精度が高くなると考えられる（3.1および 5.2 の脚注参照）。

実際に，その実験結果を図 6 に示すと，換言前音節列の適合率 $=84.2 \%$ ，再現率 $=80.2 \%$ と なり，上記の場合よりも適合率で約 $3 \% ，$ 再現率で約 $5 \%$ 高くなること，また，これらの值は計算 值によく合致することがわかった.

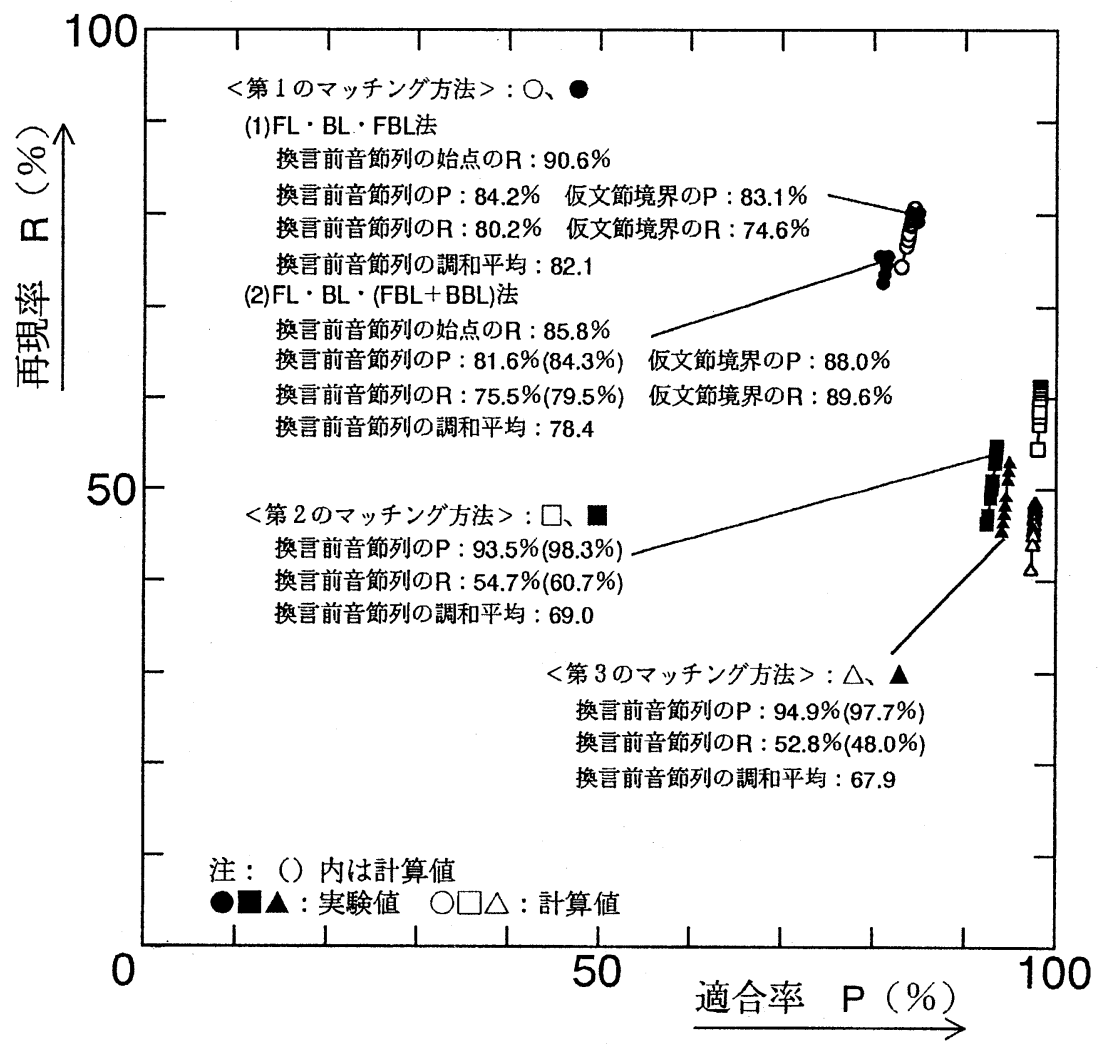

図 6 換言前音節列の抽出実験結果

\section{5 結論}

マルコフ連鎖モデルによる文節境界推定の方法と文節間の文字列比較の方法を組み合わた方 法により，会話文に現れた繰り返し型の言い直し表現は，適合率 84〜95\%，再現率 $53 \sim 80 \%$ の 精度で抽出することができる。具体的には，

（1）再現率を重視する場合には，第 1 文節境界のみを用いてマッチングにより言い直し 音節列を判定する方法が適しており，再現率=80.2\%(適合率 $=84.2 \%$ )の精度が得ら 
れる。

（2）逆に，適合率を重視する場合には，第 2 および第 3 の文節境界をも用いて文節を抽出 し，文節間の音節列を比較する方法が適しており，適合率 $=94.9 \%$ (再現率 $=52.8 \%$ ) の精度が得られる。

本方式によって得られた結果にさらに文法情報などを適用して，言い直し表現の抽出精度を 上げようとする場合は，再現率の高い (1) の結果を使用することが望ましいと考えられる。

上記の実験結果では，かなり高い精度 $(80 \%)$ で言い直し表現を抽出できることが分ったが, これは言語としての音節連鎖の持つ情報が，言い直しの言語的な特徵（誤り文字列の特性や繰 り返しの構造など）をよく反映していること，これを使用すれば従来の音響的な情報以上の効 果が得られることを意味している.

今後，抽出精度を向上するには，音節の連鎖情報に加えて，従来の音響的な情報を有機的に 組み合わせていくこと, また言語情報からみても, さらに文法的な情報を加えていくことが期 待される.

\section{6 あとがき}

本論文では，音響処理によってべた書きの音節列に変換された会話文に対して，それに含ま れる繰り返し型の言い直し表現を抽出する方法を提案した。この方法は，日本語音節列の持つ 確率的情報を利用したもので，以下の 2 つの処理から構成される。すなわち，第 1 の処理は， 言い直しの音節列が文節境界に挿入されることが多いことに着目し，言い直しを含む対話文を 文節単位に分割するもので，従来のマルコフ連鎖モデルを用いた文節境界の推定法を言い直し を含む音節列に適すように改良した，第 2 の処理は，第 1 の方法で得られた文節境界を手がか

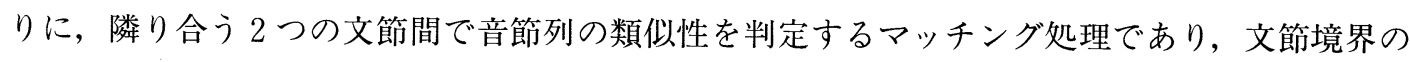
使い方の異なる 3 つの方法を提案した。

また, 提案した方法の精度を推定するため, 第 1 の処理と第 2 の処理の精度から, それを組 み合わせたときの精度を計算する方法を示した。

これらの方法を ATRの「旅行に関する対話文」データ（その内，言い直しは 106 個所）に 適用した実験結果から，以下のことが分かった。

（1）第 1 の処理では，従来のマルコフ連鎖モデルを組み合わせて使用すれば，言い直しを 含む音節列でも，言い直しを含まない場合と同程度の精度（再現率約 $90 \%$ ，適合率 88\%) で文節境界が推定できる.

（2）これにより，会話文に現れた繰り返し型の言い直し表現は，適合率 $84 \sim 95 \%$, 再現率 53 2 $2 \%$ の精度で抽出することができる.

本方式によって得られた結果にさらに文法情報などを適用して，言い直し表現の抽出精度を 
上げようとする場合は，再現率の高い方法が望まれる，その場合は，第 1 の処理で得られたす べての文節境界を起点に，それ以降数文節相当の音節列を調べる方法が適しており，その場合， 再現率 $=80.2 \%$ (適合率 $=84.2 \%$ )の精度が得られる.

なお，今後の課題としては，文節境界が未抽出の言い直し表現の抽出方法，付け加え型や繰 り返しを伴う置き換え型の言い直し表現へ適用するための拡張方法，単語境界位置に出現する 言い直し表現の抽出方法などの検討が挙げられる.

\section{謝辞}

本研究を進めるにあたり，ATR 音声言語データベースを提供下さいました ATRの関係各位 ならびに音声翻訳研究所 森元 逞 元第四研究室長に感謝いたします.

\section{参考文献}

荒木哲郎, 池原悟, 橋本昌東 (1996). “マルコフモデルによる言い直し対象の文字列の検出につ いて.”言語処理学会第 2 回年次大会, A6-1, pp. 125-128.

荒木哲郎, 池原悟, 土橋潤也, 笹島伸一 (1997). “2 重マルコフモデルを用いたべた書きかな文の 仮文節境界の推定方法.” 情処論, 38 (6), 1116-1125.

Asadi, A., Schwartz, R., and Makhoul, J. (1991). "Automatic modeling for adding new words to a large-vocaburaly continuous speech recognition system." In Proc. of the ICASSP-91, pp. 305-308.

伝康晴 (1996). “話し言葉における非文法的現象とその機械的処理.”人工知能学会 SLUD-9503-3, pp. $9-16$.

伝康晴, 春木憂, 石崎雅人 (1997). “音声対話コーパスを用いた言い直しの分析.” 情報処理学会 研究報告, SNL16-2, pp. 7-12.

江原将, 井上直己, 幸山秀雄, 長谷川敏郎, 庄山富美, 森元遈 (1990). “ATR 対話データベースの 内容.”テクニカル・レポート TR-I-0186, ATR.

井ノ上直己, 竹田一哉, 山本誠一 (1994). “ガーベジ HMM を用いた自由発話文中の不要語処理 方法.”信学論, J77-A (2), 215-222.

河原達也, 松本裕治 (1995). “音声言語処理における頑健性.” 情報処理, 36 (11), 1027-1032. 宮崎正弘 (1984). “係り受け解析を用いた複合語の自動分割法.”情処論, 25 (6), 970-979. 宮崎正弘, 大山芳史 (1986). “日本文音声出力のための言語処理方式.” 情処論, 27 (11), 1053-1061. 村上仁一，嵯峨山茂樹 (1991). “自由発話音声認識における音響的および言語的な問題点の検

討.” 信学技報, NLC91-57, SP91-100, pp. 71-78.

村上仁一, 嵯峨山茂樹 (1995). “自由発話音声における音響的な特徵の検討.” 信学論, J78-DII (12), 1741-1749. 
中川聖一, 小林聡 (1995). “自然な音声対話における間投詞・ポーズ・言い直しの出現パターン と音響的性質.” 日本音響学会誌, 51 (3), 202-210.

中野幹生, 島津明 (1997). “言い直しを含む発話の解析.” 情報処理学会研究報告, SNL16-1, pp. 1-6.

Nakatani, C. and Hirschberg, J. (1994). "A corpus-based study of repair cues in spontaneous speech." In J.Acoust. Soc. Am. 95, pp. 1603-1616.

佐川雄二, 大西昇, 杉江昇 (1994). “自己修復を含む日本語不適格文の分析とその計算機による 理解手法に関する考察.”情処学論, 35 (1), 46-52.

Shriberg, E., Bear, J., and Dowding, J. (1992). "Automatic Detection and Correction of Repairs in Human-Computer Dialog." In Proc. of the Speech and Natural Language Workshop, pp. 419-424.

Wilpon, G., Lee, C., and Rabiner, R. (1990). "Automatic recognition of keywords in unconstrained speech using hidden Markov models." In IEEE Trans. ASSP-38, 11, pp. $1870-1878$.

山本幹雄, 小林聡, 中川聖一 (1992). “音声対話文における助詞落ち、倒置の分析解析手法.” 情 処論, 33 (11), 1322-1330.

\section{略歴}

荒木 哲郎: 1948 年生. 1976 年福井大学工学部電気工学科卒業. 1981 年東北 大学大学院博士課程修了。同年，日本電信電話公社入社，1990 年 NTT 退 社, 同年福井大学工学部電子工学科助教授, 現在に至る. 自然言語処理, 知 識情報処理の研究に従事。電子情報通信学会, 情報処理学会, 言語処理学会, IEEE，各会員.

池原 悟: 1944 年生. 1967 年大阪大学基礎工学部電気工学科卒業. 1969 年同 大学大学院修士課程修了. 同年, 電信電話公社に入社. 数式処理, トラヒッ ク理論, 自然言語処理の研究に従事. 1996 年より，スタンフォード大学客員 教授. 現在，鳥取大学工学部教授. 工学博士. 1982 年情報処理学会論文賞, 1993 年同研究賞. 1995 年日本科学技術セン夕賞 (学術賞), 同年人工知能学 会論文賞. 電子情報通信学会, 人工知能学会, 言語処理学会, 各会員.

橋本 昌東: 1972 年生. 1995 年福井大学工学部電子工学科卒業. 1999 年同大 学大学院博士前期課程修了。同年 4 月日本電気株式会社に入社. 現在, 第 2 パーソナル C\&C 事業部に勤務. 